\title{
Penambahan CMC, Gum Xanthan, dan Pektin sebagai Stabilizer pada Sirup Air Kelapa
}

(The Addition of CMC, Gum Xanthan, and Pectin as the Stabilizers in Coconut Water Syrup)

\author{
Maulidita Agustina ${ }^{1}$, Fahrizal $^{1}$, Eti Indarti ${ }^{1 *}$ \\ ${ }^{1}$ Program Studi Teknologi Hasil Pertanian, Fakultas Pertanian, Universitas Syiah Kuala
}

\begin{abstract}
Abstrak. Sirup air kelapa merupakan minuman ringan berupa larutan kental dengan cita rasa air kelapa yang diolah melalui proses evaporasi. Selama penyimpanan, timbul lapisan di permukaan sirup air kelapa yang diduga merupakan lemak. Penelitian ini bertujuan untuk memperoleh jenis stabilizer terbaik untuk sirup air kelapa. Penelitian ini dilakukan dengan menggunakan Rancangan Acak Lengkap (RAL) satu faktor yaitu jenis stabilizer (M) yang terdiri atas 3 taraf yaitu M1=CMC (0,75\%), M2=xanthan gum $(0,075 \%)$, dan M3=pektin $(0,5 \%)$ Hasil penelitian menunjukkan bahwa jenis stabilizer tidak berpengaruh nyata terhadap $\mathrm{pH}$, total padatan terlarut, dan kestabilan emulsi. Berdasarkan perhitungan skor prioritas, CMC dan xanthan gum memperoleh nilai yang lebih tinggi dibandingkan pektin. Berdasarkan perhitungan harga bahan penstabil dikalikan konsentrasi penstabil yang digunakan dalam pembuatan sirup, xanthan gum diperoleh sebagai penstabil yang lebih baik dibandingkan CMC dan pektin.
\end{abstract}

Kata Kunci: Sirup, kelapa, stabilizer, CMC, xanthan gum, pektin

\begin{abstract}
Coconut water syrup is a soft drink in the form of thick solution with the taste of coconut water which processed through evaporation. During storage, fat layer appeared on the surface of coconut water. The purpose of this research is to obtain the best stabilizer for coconut water syrup. This research used a Randomized Complete Design (RBD) with one factor that is the type of stabilizer (M), consist of 3 levels which are M1 $=$ CMC $(0.75 \%)$, $\mathrm{M} 2=$ xanthan gum $(0.075 \%)$, and M3 = pectin $(0,5 \%)$. The result shows that the type of stabilizer has no significant effect on $\mathrm{pH}$, total dissolved solids, and emulsion stability. The priority score calculation shows that CMC and xanthan gum obtain a higher value than pectin. Based on the calculation of the stabilizers' price multiplied by the stabilizers' concentration, xanthan gum is a better stabilizer than CMC and pectin.
\end{abstract}

Keywords: Syrup, coconut, stabilizer, CMC, xanthan gum, pectin.

\section{PENDAHULUAN}

Tanaman kelapa merupakan tanaman perkebunan yang termasuk ke dalam anggota dari famili Arecaceae yang merupakan spesies dalam genus Cocos. Tanaman kelapa memiliki banyak manfaat mulai dari akar hingga ke ujung daunnya. Air kelapa yang dihasilkan dari buah kelapa yang sudah tua biasanya dibuang karena dianggap sebagai limbah oleh masyarakat. Akan tetapi, air kelapa tua tersebut sebagaia besar sudah digunakan untuk dijadikan berbagai macam produk misalnya kecap, nata de coco, cuka, dan sirup air kelapa (Johan, 2000).

Sirup air kelapa merupakan minuman ringan berupa larutan kental dengan cita rasa air kelapa yang diolah melalui proses evaporasi, sehingga untuk mengkonsumsinya perlu diencerkan terlebih dahulu dengan air. Sirup air kelapa yang diproduksi selama ini sangat cepat mengalami perubahan fisik dan kimia saat penyimpanannya yaitu timbul lapisan di permukaan sirup. Perubahan tersebut berdampak pada penurunan mutu sirup. Lapisan tersebut diduga adalah lemak yang terpisah dari bahan baku. Agar lemak tidak terpisah perlu ditambahkan bahan penstabil (stabilizer) pada sirup air kelapa. Penstabil (stabilizer) merupakan bahan aditif makanan yang digunakan untuk menstabilkan sistem dispersi yang homogen pada produk pangan. Contoh stabilizer antara lain CMC, xanthan gum, dan pektin (Kementrian Kesehatan Republik Indonesia, 2012). 
Konsentrasi bahan penstabil yang umum digunakan adalah kurang dari 1\%, karena pada konsentrasi tersebut sudah menghasilkan kekentalan yang cukup tinggi. Konsentrasi bahan penstabil yang melebihi 1\% akan menyebabkan produk berubah menjadi gel (Tranggono et al., 1990). Berdasarkan penelitian Ramadhiana (2013) pada pembuatan sirup asam jawa dengan penambahan CMC $(0,25 \%, 0,50 \%$, dan 0,75\%), kestabilan sirup asam jawa terbaik diperoleh pada konsentrasi 0,75\%. Pada penelitian menggunakan xanthan gum $(0,025 \%, 0,050 \%$, dan 0,075\%) pada pembuatan sirup asam jawa, diperoleh bahwa konsentrasi xanthan gum 0,075\% menghasilkan sirup terbaik (Christina, 2005). Sedangkan menurut penelitian Azman (2010), penggunaan pektin sebagai penstabil sirup jeruk dengan konsentrasi $0,5 \%$ menghasilkan hasil yang terbaik di antara sirup dengan konsentrasi pektin 0\%,0,5\%, 1\%, dan 1,5\%. Pada penelitian ini, ketiga jenis bahan stabilizer (CMC, xanthan gum, dan pektin) akan digunakan untuk mengkaji jenis stabilizer yang paling sesuai untuk digunakan pada pembuatan sirup air kelapa.

\section{METODE PENELITIAN}

Penelitian ini dilaksanakan pada bulan Mei 2018. Penelitian dilakukan di Laboratorium Rekayasa Proses Pangan dan Industri, Laboratorium Mikrobiologi Pangan dan Industri, dan Laboratorium Analisis Pangan dan Hasil Pertanian, Fakultas Pertanian, Universitas Syiah Kuala, Darussalam, Banda Aceh.

\section{Bahan dan Alat}

Bahan yang digunakan dalam penelitian pembuatan sirup air kelapa antara lain adalah air kelapa dari buah yang telah tua (7-8 bulan) yang diperoleh dari pasar Rukoh. Air kelapa segera diolah paling lambat 2 jam setelah dikeluarkan dari buah kelapa. Bahan tambahan yang digunakan yaitu gula pasir, stabilizer (CMC, xanthan gum, dan pektin), asam benzoat, dan essen pandan. Bahan yang digunakan untuk analisis adalah aquades dan larutan buffer.

Alat-alat yang digunakan dalam pembuatan sirup air kelapa adalah kompor gas, panci stainless steel, pengaduk, kain saring, gelas ukur, timbangan analitik, autoclave, botol kaca bening, dan alat pengemas. Sedangkan alat-alat yang digunakan untuk analisis yaitu beaker glass, $\mathrm{pH}$ meter, refraktometer, dan tabung sentrifuge.

\section{Rancangan Penelitian}

Penelitian ini dilakukan dengan menggunakan Rancangan Acak Lengkap (RAL) satu faktor yaitu jenis stabilizer (M) yang terdiri atas 3 taraf (CMC 0,75\%, xanthan gum 0,075\%, dan pektin $0,5 \%$ ) dengan 3 kali ulangan sehingga diperoleh 9 satuan percobaan.

\section{Analisis Data}

Analisis dilakukan meliputi nilai $\mathrm{pH}$, total padatan terlarut, dan kestabilan emulsi. Untuk menguji pengaruh dari setiap faktor terhadap parameter analisis, dilakukan analisis statistik dengan menggunakan ANOVA (Analysis of varians). Bila terdapat pengaruh yang nyata antara perlakuan maka dilanjutkan dengan uji lanjut Beda Nyata Terkecil (BNT).

Pengaruh Penambahan Stabilizer terhadap Kestabilan Sirup Sirup Air Kelapa (Cocos nucifera) (Maulidita Agustina, Fahrizal, Eti Indarti)

Jurnal Ilmiah Mahasiswa Pertanian, Vol. 4 No. 2, Mei 2019: 266-273 


\section{Prosedur Penelitian}

Proses pembuatan sirup air kelapa dilakukan menurut Agustina (2012) dengan sedikit modifikasi. Air kelapa yang diperoleh dari pedagang ( $\leq 2$ jam setelah dibelah) disaring dengan menggunakan kain saring. Selanjutnya, air kelapa dimasak selama 15 menit. Selama pemanasan, gula pasir ditambahkan dengan perbandingan gula pasir dan air kelapa 1:1 sambil diaduk hingga gula larut sempurna. Stabilizer (CMC 0,75\%, xanthan gum 0,075\%, dan pektin 0,5\%), asam benzoat $0,3 \%$, dan essen $0,5 \%$ ditambahkan ke dalam sirup setelah sirup masak. Sirup didinginkan hingga mencapai suhu $70^{\circ} \mathrm{C}$. Selanjutnya, sirup air kelapa dimasukkan ke dalam botol yang telah disterilisasi menggunakan autoclave dengan suhu $121^{\circ} \mathrm{C}$ selama 15 menit dan botol sirup ditutup segera untuk mencegah rekontaminasi.

\section{Analisis}

Analisis yang dilakukan pada sirup air kelapa meliputi analisis $\mathrm{pH}$, kestabilan emulsi, dan total padatan terlarut.

\section{HASIL DAN PEMBAHASAN}

\section{pH}

Pengujian $\mathrm{pH}$ merupakan salah satu parameter penting karena nilai $\mathrm{pH}$ yang stabil menunjukkan bahwa proses distribusi dari bahan dasar dalam sediaan merata. Nilai pH yang dianjurkan untuk sirup berkisar antara 4-7 (Standar Nasional Indonesia, 1995).

Hasil uji pH sirup air kelapa pada penelitian ini berkisar antara 5,30 sampai dengan 5,66 dengan rata-rata 5,46. Berdasarkan hasil analisis ragam, perbedaan jenis stabilizer berpengaruh tidak nyata terhadap $\mathrm{pH}$ sirup yang dihasilkan. Hasil uji $\mathrm{pH}$ sirup yang diperoleh dari penelitian ini bersesuaian dengan hasil uji $\mathrm{pH}$ sirup air kelapa yang diperoleh dari penelitian Zaldiansyah (2018) dengan nilai rata-rata 5,48. Nilai rata-rata $\mathrm{pH}$ sirup air kelapa yang diperoleh dengan penambahan xanthan gum yaitu 5,53, lebih tinggi dari nilai rata-rata $\mathrm{pH}$ sirup air kelapa dengan penambahan CMC $(5,50)$ dan pektin $(5,35)$. Sirup dengan penambahan ketiga penstabil menghasilkan sirup dengan nilai $\mathrm{pH}$ yang masih dalam batas nilai $\mathrm{pH}$ yang dianjurkan untuk sirup yaitu berkisar antara 4-7 (Standar Nasional Indonesia, 1995).

$\mathrm{pH}$ dalam suatu produk (sirup) dipengaruhi oleh $\mathrm{pH}$ masing-masing bahan penyusun dan konsentrasi bahan penyusun tersebut. Di dalam proses pembuatan sirup pada penelitian ini, bahan yang digunakan adalah gula, air kelapa, benzoat, essen, dengan jumlah dan konsentrasi yang sama, sedangkan stabilizer yang digunakan pada konsentrasi yang berbeda.

pH air kelapa diketahui memiliki $\mathrm{pH}$ 3,4-5 (Agustina, 2012). Terjadi peningkatan $\mathrm{pH}$ sirup air kelapa disebabkan oleh jumlah dan konsentrasi bahan penstabil. Ganz (1997) CMC merupakan gum hidrokoloid yang mengandung banyak gugus karboksil dan mudah terhidrolisis yang menyebabkan nilai $\mathrm{pH}$ pada bahan meningkat. Semakin tinggi konsentrasi CMC yang ditambahkan ke dalam bahan, maka akan meningkatkan nilai $\mathrm{pH}$ bahan.

\section{Total Padatan Terlarut}

Total padatan terlarut di dalam larutan menunjukkan banyaknya kandungan bahan-bahan yang terlarut. Menurut Susanto (1986) dalam Yusuf (2002), total padatan terlarut di dalam minuman ringan sebagaian besar merupakan gula.

Pengaruh Penambahan Stabilizer terhadap Kestabilan Sirup Sirup Air Kelapa (Cocos nucifera) (Maulidita Agustina, Fahrizal, Eti Indarti)

Jurnal Ilmiah Mahasiswa Pertanian, Vol. 4 No. 2, Mei 2019: 266-273 
Hasil uji total padatan terlarut yang dihasilkan pada sirup air kelapa berkisar antara 0,90$3,00\left({ }^{\circ}\right.$ Brix) dengan rata-rata $1,51^{\circ}$ Brix. Hasil analisis ragam menunjukkan bahwa perbedaan jenis stabilizer tidak berpengaruh nyata terhadap total padatan terlarut sirup yang dihasilkan. Pada penelitian Ramadhiana (2013) yang menggunakan 3 jenis penstabil (CMC, xanthan gum, dan gum arab), jenis bahan penstabil juga tidak memberikan pengaruh nyata terhadap total padatan terlarut sirup asam jawa.

Hasil uji total padatan terlarut sirup air kelapa dengan penambahan pektin menghasilkan nilai yang lebih tinggi yaitu $1,67^{\circ}$ Brix dibandingkan sirup dengan penambahan $\mathrm{CMC}\left(1,27^{\circ} \mathrm{Brix}\right)$ dan xanthan gum $\left(1,60^{\circ}\right.$ Brix $)$. Penambahan penstabil ke dalam produk pangan akan meningkatkan total padatan terlarut. Jika konsentrasi penstabil yang ditambahkan semakin tinggi, maka total padatan terlarutnya pun meningkat. Peningkatan ini disebabkan karna pahan penstabil mengikat air sehingga konsentrasi bahan meningkat. Semakin banyak partikel yang terikat oleh bahan penstabil, maka partikel-partikel yang tersuspensi akan terperangkap dalam sistem tersebut (Potter dan Hotchkiss, 1995 dalam Kusumah, 2007).

Prabandari (2011) menyatakan bahwa peningkatan konsentrasi bahan penstabil akan diikuti dengan peningkatan jumlah total padatan terlarut. Penambahan bahan penstabil menyebabkan total padatan terlarut meningkat karena CMC, xanthan gum, dan pektin mampu mengikat dengan baik gula, air, asam-asam organik, dan komponen-komponen lainnya. Kestabilan larutan meningkat karena air, gula, asam-asam organik, dan komponen-komponen lainnya terikat sehingga padatan terlarutnya akan lebih tinggi.

\section{Kestabilan Emulsi}

Hasil uji kestabilan emulsi sirup air kelapa berkisar antara $76.56 \%$ sampai dengan $97.56 \%$ dengan rata-rata $91,13 \%$. Berdasarkan hasil analisis ragam, jenis stabilizer berpengaruh tidak nyata terhadap kestabilan emulsi sirup yang dihasilkan. Hasil uji kestabilan emulsi sirup air kelapa dengan penambahan CMC menghasilkan nilai yang lebih tinggi $(93,33 \%)$ dibandingkan sirup dengan penambahan xanthan gum $(93,20 \%)$ dan pektin $(86,87 \%)$.

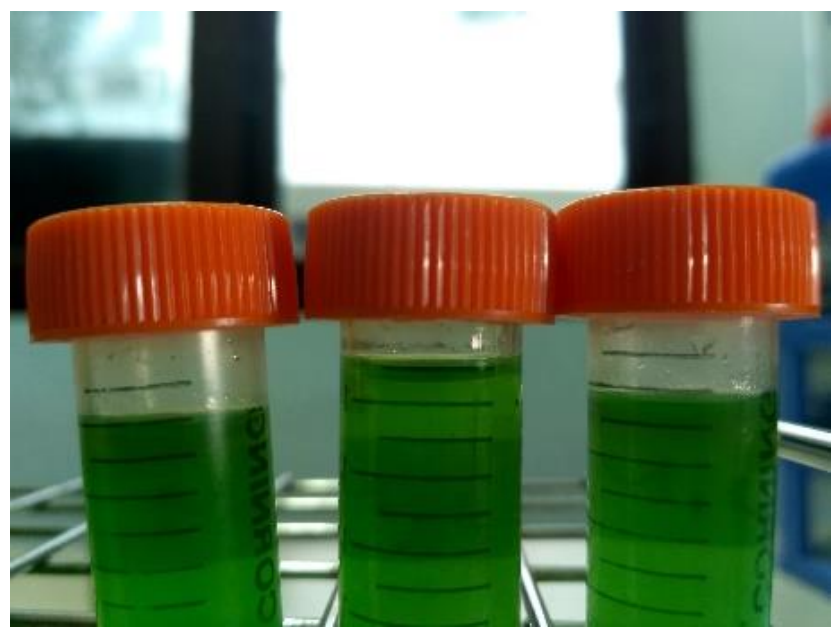

Gambar 1. Hasil uji kestabilan emulsi sirup air kelapa dengan penambahan CMC

Pengaruh Penambahan Stabilizer terhadap Kestabilan Sirup Sirup Air Kelapa (Cocos nucifera) (Maulidita Agustina, Fahrizal, Eti Indarti)

Jurnal Ilmiah Mahasiswa Pertanian, Vol. 4 No. 2, Mei 2019: 266-273 


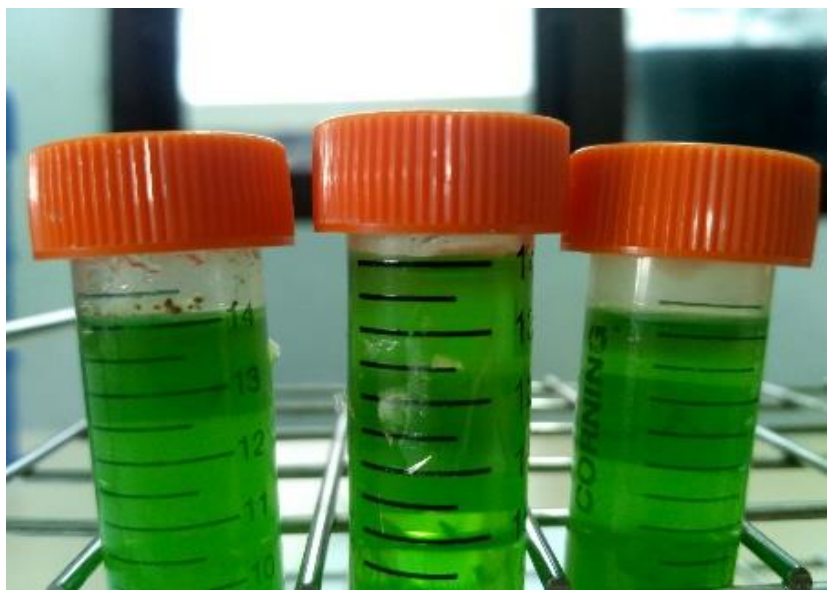

Gambar 2. Hasil uji kestabilan emulsi sirup air kelapa dengan penambahan xanthan gum

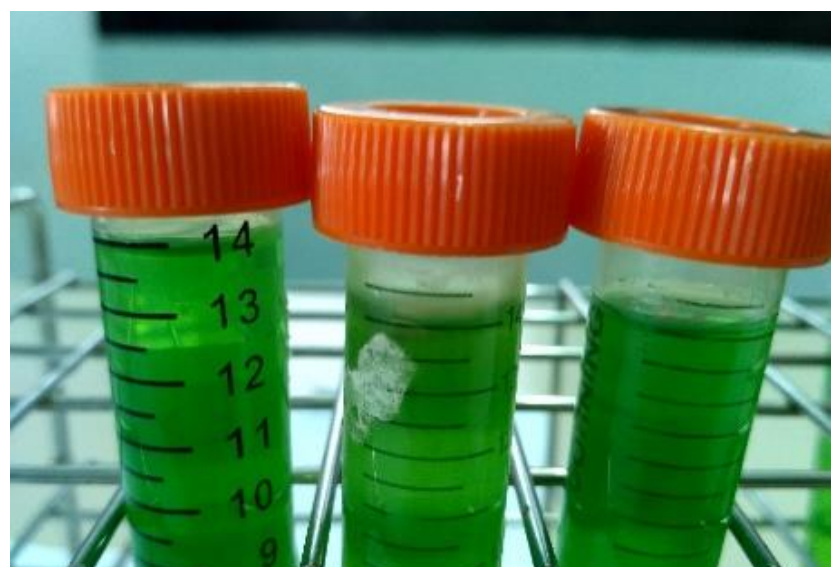

Gambar 3. Hasil uji kestabilan emulsi sirup air kelapa dengan penambahan pektin

Hal ini diduga adanya perbedaan konsentrasi dari penggunaan masing-masing stabilizer. Pada penelitian ini, konsentrasi stabilizer dipilih berdasarkan hasil terbaik pada penelitian terdahulu yaitu CMC 0,75\% (Ramadhiana, 2013), xanthan gum 0,075\% (Christina, 2005), dan pektin 0,5\% (Azman, 2010). Meskipun stabilizer yang digunakan memiliki konsentrasi berbeda, tetapi tidak mempengaruhi kestabilan emulsi dari sirup yang dihasilkan.

Dari struktur kimia ketiga stabilizer, ketiganya memiliki gugus karboksil dan gugus hidroksil terlihat pada Gambar 4. Kedua gugus ini berperan dalam proses penstabilan pada sirup. Gugus karboksil dan hidroksil memiliki sifat hidrofilik sehingga mampu berperan sebagai pengental atau penstabil dalam larutan yang banyak mengandung air membentuk ikatan hidrogen.

Dari Gambar 4, CMC memiliki 2 gugus karboksil sedangkan xanthan gum dan pektin hanya memiliki 1 gugus karboksil setiap unit monomernya (ditandai dengan warna merah). Dibandingkan gugus hidroksil, gugus karboksil memiliki muatan negatif yang lebih tinggi (Orata, 2012) sehingga CMC yang memiliki gugus karboksil lebih banyak akan lebih bertahan kestabilannya dibandingkan bahan yang gugus karboksilnya lebih rendah. Xanthan gum memiliki

Pengaruh Penambahan Stabilizer terhadap Kestabilan Sirup Sirup Air Kelapa (Cocos nucifera) (Maulidita Agustina, Fahrizal, Eti Indarti)

Jurnal Ilmiah Mahasiswa Pertanian, Vol. 4 No. 2, Mei 2019: 266-273 
gugus hidroksil yang lebih banyak dibandingkan CMC dan pektin sehingga walaupun digunakan dalam konsentrasi sedikit mampu mempertahankan kestabilan sirup.
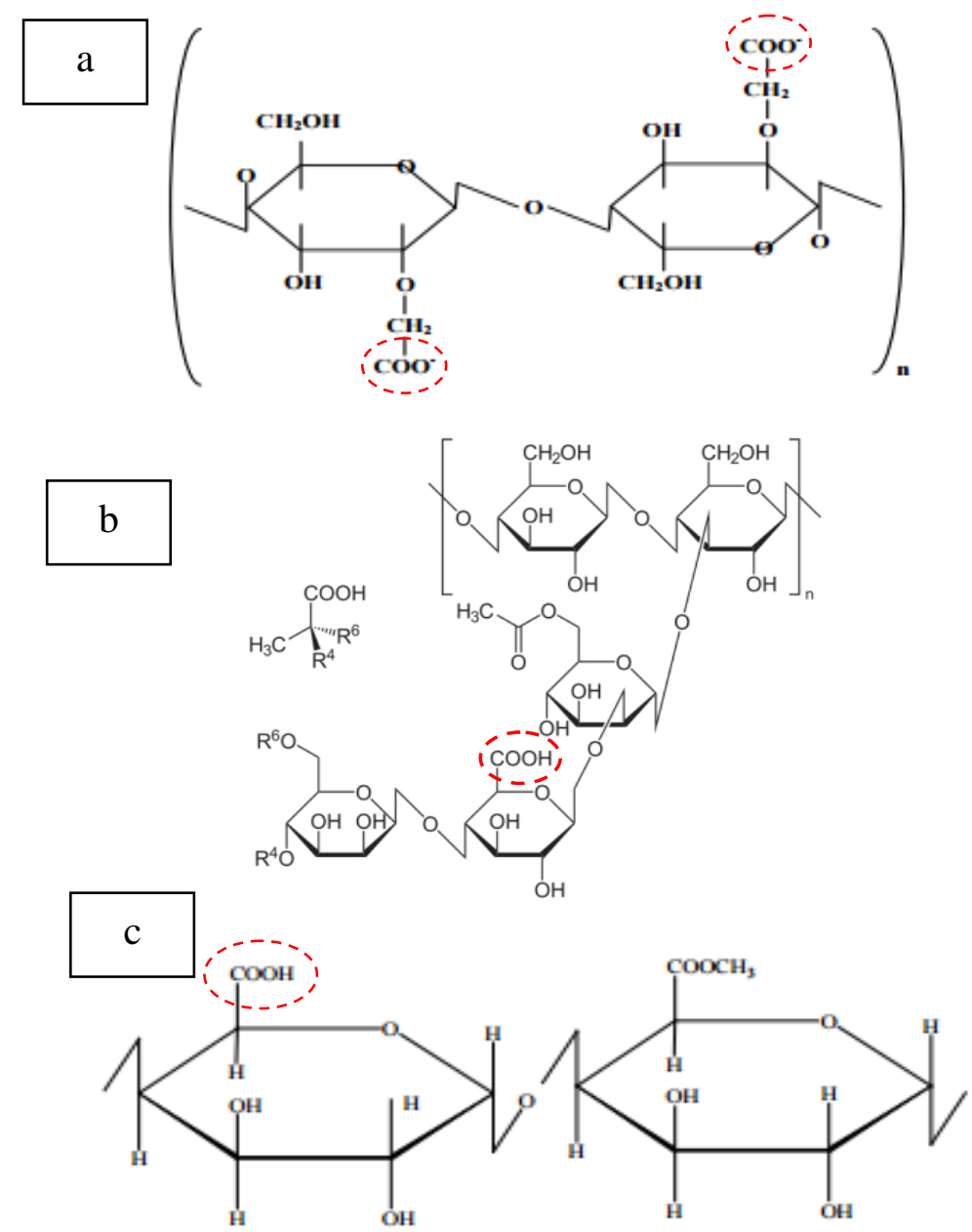

Gambar 4. Struktur kimia emulsifier (a: CMC, b: xanthan gum, dan c: pektin)

Selain itu daripada itu, faktor lain yang mempengaruhi adalah unit bercabang yang terdapat pada unit monomer stabilizer juga akan mempengaruhi kestabilan emulsi. Semakin banyak rantai bercabang akan menghasilkan kemampuan berikatan dengan air yang semakin tinggi. Dari Gambar 2 dapat dilihat bahwa xanthan gum memiliki unit yang bercabang dibandingkan CMC dan pektin, sehingga meskipun digunakan dalam konsentrasi yang rendah, nilai kestabilan emulsi sirup dengan penambahan xanthan gum $(93,20 \%)$ sangat mendekati nilai kestabilan emulsi sirup dengan penambahan CMC (93,33\%).

Pengaruh Penambahan Stabilizer terhadap Kestabilan Sirup Sirup Air Kelapa (Cocos nucifera) (Maulidita Agustina, Fahrizal, Eti Indarti)

Jurnal Ilmiah Mahasiswa Pertanian, Vol. 4 No. 2, Mei 2019: 266-273 


\section{Penentuan Stabilizer Terbaik}

Untuk menentukan kondisi terbaik, setiap parameter dilakukan skoring dan penentuan prioritas. Prioritas tertinggi hingga ke terendah akan diberi bobot persentasi 50\%, 25\%, dan $25 \%$. Bahan penstabil dengan total nilai yang paling tinggi dipilih sebagai stabilizer untuk sirup air kelapa.

Tabel 1. Penentuan skor prioritas

\begin{tabular}{lccccccc}
\hline & $\mathrm{pH}$ & Nilai & $\begin{array}{c}\text { Total } \\
\text { Padatan } \\
\text { Terlarut }\end{array}$ & Nilai & $\begin{array}{c}\text { Kestabilan } \\
\text { Emulsi }\end{array}$ & Nilai & Total Nilai \\
\hline Bobot & $25 \%$ & $\mathrm{a}$ & $25 \%$ & $\mathrm{~b}$ & $50 \%$ & $\mathrm{c}$ & $\mathrm{a}+\mathrm{b}+\mathrm{c}$ \\
CMC & 2 & 0,5 & 1 & 0,25 & 3 & 1,5 & 2,25 \\
Xanthan & 3 & 0,75 & 2 & 0,5 & 2 & 1 & 2,25 \\
gum & 1 & 0,25 & 3 & 0,75 & 1 & 0,5 & 2 \\
Pektin & & & & & & & \\
\hline
\end{tabular}

Berdasarkan perhitungan penentuan skor (Tabel 1), CMC dan xanthan gum memperoleh total nilai yang sama yaitu 2,25, sedangkan pektin memperoleh total nilai 2. Karena CMC dan xanthan gum memperoleh total nilai yang sama, maka dihitung harga stabilizer yang digunakan dalam setiap liter yaitu dengan cara harga stabilizer dikalikan konsentrasi yang digunakan. Berdasarkan hasil perhitungan (Tabel 2) diperoleh bahwa xanthan gum lebih lebih murah (Rp 1.725) dibandingkan CMC (Rp 11.250) dan pektin (Rp 18.000), sehingga didapatkan xanthan gum sebagai stabilizer yang lebih baik untuk sirup air kelapa dibandingkan CMC dan pektin.

Tabel 2. Penentuan harga

\begin{tabular}{lccc}
\hline & $\begin{array}{c}\text { Harga/100g } \\
(\mathrm{Rp})\end{array}$ & $\begin{array}{c}\text { Konsentrasi/1L } \\
(\%)\end{array}$ & Harga x Konsentrasi \\
\hline CMC & 15.000 & 0,75 & 11.250 \\
Xanthan Gum & 23.000 & 0,075 & 1.725 \\
Pektin & 36.000 & 0,5 & 18.000 \\
\hline
\end{tabular}

\section{KESIMPULAN}

Jenis stabilizer berpengaruh tidak nyata terhadap $\mathrm{pH}$, total padatan terlarut, dan kestabilan emulsi. Hasil uji pH sirup dengan penambahan xanthan gum menghasilkan nilai yang lebih tinggi yaitu 5,53. Hasil uji total padatan terlarut dengan penambahan pektin menghasilkan nilai yang lebih tinggi yaitu 1,67. Hasil uji kestabilan emulsi dengan penambahan CMC menghasilkan nilai lebih tinggi yaitu 93,33\%. Berdasarkan penentuan skor dan harga, diperoleh bahwa xanthan gum adalah stabilizer yang lebih baik untuk sirup air kelapa.

Pengaruh Penambahan Stabilizer terhadap Kestabilan Sirup Sirup Air Kelapa (Cocos nucifera) (Maulidita Agustina, Fahrizal, Eti Indarti)

Jurnal Ilmiah Mahasiswa Pertanian, Vol. 4 No. 2, Mei 2019: 266-273 


\section{DAFTAR PUSTAKA}

Agustina, C. A. 2012. Pengaruh penambahan asam benzoat dan lama penyimpanan terhadap mutu sirup air kelapa (Cocos nucifera). Jurusan Teknologi Hasil Pertanian Universitas Syiah Kuala, Banda Aceh.

Azman. 2010. Pengaruh Penambahan Penstabil Pektin dan CMC terhadap Mutu Sirup Jeruk. Karya Ilmiah Peneliti dan Penyuluh, Sumatera Barat.

Christina, S. 2005. Pengaruh jenis dan konsentrasi zat penstabil terhadap mutu sirup asam jawa

(Tamarindus indica L.). Skripsi. Jurusan Teknologi Pertanian Fakultas Pertanian Universitas Sumatera Utara, Medan

Ganz, A. J. 1997. Cellulosa Hydrocolloid. Avi Publishing CO. Inc. Westport, Connecticut.

Johan, H. 2000. Kecap Air Kelapa. Lipi-Press, Jakarta.

Kementrian Kesehatan Republik Indonesia. 2012. Peraturan Menteri Kesehatan RI Nomor 033 Tahun 2012 tentang Bahan Tambahan Makanan. Kemenkes RI, Jakarta.

Kusumah, R.A. 2007. Optimasi kecukupan panas melalui pengukuran distribusi dan penetrasi panas pada formulasi minuman sari buah pala (Myristica fragrans HOUTT). Skripsi. Fateta. IPB, Bogor.

Orata, F. 2012. Derivatization reactions dan reagents for gas chromatography analysis. INTECH Open Access Publisher, Rijeka.

Prabandari, W. 2011. Pengaruh penambahan berbagai jenis bahan penstabil terhadap karakteristik fisikokimia dan organoleptik yoghurt jagung. Skripsi. Fakultas Pertanian Universitas Sebelas Maret, Surakarta.

Ramadhiana, F. 2013. Pengaruh jenis dan konsentrasi penstabil terhadap kestabilan sirup asam jawa. Skripsi. Jurusan Teknologi Hasil Pertanian Fakultas Pertanian Universitas Syiah Kuala, Banda Aceh.

Standar Nasional Indonesia. 1995. SNI Minuman Sirup Buah. Dewan Standardisasi Nasional. Jakarta.

Tranggono, Sutardi, Haryadu, Suparmo, Nurdiati A., Sidarmaji S., Rahayu K., Narui S., Atuti M. 1990. Bahan Tambahan Pangan (Food Additives). Pusat Antar Universitas Pangan dan Gizi UGM, Yogyakarta.

Yusuf, R. R. 2002. Formulasi, karakteristik kimia, dan uji aktivitas antioksidan produk minuman funggsional sari jahe (Zingiber officinale Rosc.) dan sari sereh dapur (Cymbopogon flexousus). Skripsi. Fakultas Teknologi Pertanian. IPB, Bogor.

Zaldiansyah, T. 2018. Kajian pembuatan sirup air kelapa (Cocos nucifera) dengan penambahan gula fruktosa sebagai alternatif pengganti gula sukrosa. Skripsi. Jurusan Teknologi Hasil Pertanian Universitas Syiah Kuala, Banda Aceh.

Pengaruh Penambahan Stabilizer terhadap Kestabilan Sirup Sirup Air Kelapa (Cocos nucifera) (Maulidita Agustina, Fahrizal, Eti Indarti)

Jurnal Ilmiah Mahasiswa Pertanian, Vol. 4 No. 2, Mei 2019: 266-273 